\title{
Teaching work routine: challenges to nursing professors in contemporary times*
}

\author{
Cotidiano laboral docente: enfrentamentos dos professores \\ de enfermagem na contemporaneidade \\ Cotidiano laboral docente: enfrentamientos de los profesores \\ de enfermería en la contemporaneidad
}

How to cite this article:

D'Oliveira CAFB, Souza NVDO, Varella TCMML, Vargens OMC, Noronha IR, Noronha IR. Teaching work routine: challenges to nursing professors in contemporary times. Rev Esc Enferm USP. 2020;54:e03577. doi: https://doi.org/10.1590/S1980-220X2018038603577

\section{Camila Arantes Ferreira Brecht D'Oliveira $^{1}$ \\ iD Norma Valéria Dantas de Oliveira Souza ${ }^{2}$ \\ (iD) Thereza Christina Mó Y Mó Loureiro Varella ${ }^{3}$

(D) Octávio Muniz da Costa Vargens ${ }^{4}$
(D) Isabela da Rosa Noronha ${ }^{2}$
(D) Isabele da Rosa Noronha ${ }^{2}$

* Extracted from the dissertation: "O reconhecimento e a valorização profissional do docente de enfermagem no contexto neoliberal”, Programa de Pós-Graduação em Enfermagem, Faculdade de Enfermagem, Universidade do Estado do Rio de Janeiro, 2017.

${ }^{1}$ Fundação Oswaldo Cruz, Escola Nacional de Saúde Pública, Rio de Janeiro, RJ, Brazil.

${ }^{2}$ Universidade do Estado do Rio de Janeiro, Faculdade de Enfermagem, Rio de Janeiro, RJ, Brazil.

${ }^{3}$ Universidade do Estado do Rio de Janeiro, Faculdade de Enfermagem, Departamento de Enfermagem de Saúde Pública, Rio de Janeiro, RJ, Brazil.

${ }^{4}$ Universidade do Estado do Rio de Janeiro, Faculdade de Enfermagem, Departamento de Enfermagem MaternoInfantil, Rio de Janeiro, RJ, Brazil.

\begin{abstract}
Objective: To describe the organization of nursing professors' work and analyze its limiting and facilitating aspects. Method: A qualitative and descriptive study composed of professors from the federal public universities of Rio de Janeiro. Data collection took place through semi-structured interviews. The content analysis technique was used for data processing. Results: Twenty-seven (27) professors participated. Facilitating elements of the teaching work were: work environment; autonomy and flexibility; liking what they do; use of technologies; and solidarity of the professional group; while hindering elements included: high work demand; intense work rhythm; scarcity of material and human resources; and academic competitiveness. Conclusion: The configuration of the teaching work organization is complex and multifaceted, presenting high psychoaffective, cognitive and physical demands which enhance illness in these workers.
\end{abstract}

\section{DESCRIPTORS}

Faculty, Nursing; Working Conditions; Models, Economic; Occupational Health.
Corresponding author:

Camila Arantes Ferreira Brecht D'Oliveira

Rua Luiz Barbosa, 94 Apto 101 frente, Vila Isabel

CEP:20.560-010 Rio de Janeiro, RJ, Brazil

camilabrechtuerj@gmail.com
Received: 08/29/2018

Approved: 08/29/2019 


\section{INTRODUCTION}

Work is defined as the ability of an individual to alter the state of materials from nature, improving their usefulness. Thus, in the broad sense, work is all human activity which changes the nature of a given matter, incorporating the usage value of this workforce in it, primarily with a view to maintain livelihoods ${ }^{(1)}$. However, work is not only characterized as a means of material survival; it is also a form of socialization, identity building and social status. Depending on the way it happens, the configuration of work can rescue or promote health, or can potentiate worker illness ${ }^{(2)}$.

Work organization is the process of delegating people and tasks into production. It contains hierarchies, commands, cadences, a division of responsibilities and work tasks ${ }^{(3)}$. Such a process is based on precepts of the economic models, which dictate the production form.

Capitalist production modes include Taylorism, which emerged in the mid-twentieth century and focused on dividing tasks and consequently fragmenting the production process. Fordism emerged as an evolution of Taylorism, maintaining production mechanization and inserting the conveyor belt; this set a new and intense pace for the work process. Toyotism then emerged in the mid-1960s with the decline of Fordism, characterized as a flexible form of production based on the execution of teamwork, cooperation, continuous improvement of production and "just in time" (4).

This production mode was aimed at containing costs, and producing exactly enough to meet market demand. In this context, the employee, who previously performed a specific function, became responsible for various functions and for performing them according to the needs of the company. With this premise of flexible accumulation, the neoliberal model then emerged in the mid-1970s ${ }^{(5)}$.

This model, whose origin comes from liberal thought, can be at first defined as an economic policy which argues that the state does not participate in the economy. Its consolidation in Brazil took place in the 1990s, having "minimum state" and "maximum market" as its programmatic base, as well as the indiscriminate opening of the national economy to the international market. In this logic, the minimum was proposed for workers and the maximum for capital ${ }^{(6)}$.

Several forms of hiring workers emerge from implementing this model, resulting in the flexibilization of labor contracts and consequently a loss of labor rights, added to the increase in structural unemployment. There is devaluation of the labor force because in addition to demanding an intense production rhythm from the employees and offering low wages, they increase the competitiveness and the stress in the work environments ${ }^{(5)}$.

The influence of neoliberal precepts has been so marked in the world and in Brazil that labor organizations, whether private or public, have systematically and increasingly applied such precepts to productivity in order to maximize results and profits. The educational sector has not distanced itself from this context, especially observing the adoption of neoliberal principles in universities since the $2000 \mathrm{~s}^{(5,7)}$. Such influence of neoliberalism in university institutions considerably transformed the teaching work process, introducing repercussions to the health of these workers and for the productive logic of the teaching-learning process ${ }^{(6-7)}$.

Teaching work falls within this context with the purpose to educate/train subjects who will be capable of critically analyzing social reality, aiming toward its positive transformation, either by direct pedagogical action of the teacher or insidious construction of critical sense in students through examples of conduct of the pedagogical faculty ${ }^{(7)}$.

In order to achieve this goal, it is important that the teacher develops skills and competencies, especially empathy and communication, in order to equip themselves to obtain a better relationship with the students. Constant theoretical and practical improvement is also necessary, as well as meeting scientific-academic requirements such as performing systematic readings, scientific publications, participation in scientific events and work guidelines, among other specific activities of this professional ${ }^{(8)}$.

The demands and pressure on the teacher have increased considerably with the advent of neoliberalism in the labor organizations of the education sector, making the teacher, in addition to teaching with excellence, intensify their research production and publications in international journals with high scientific impact. Thus, the versatility and multifunctionality of this worker is mainly configured due to a reduction in human resources, especially of technical and administrative staff, resulting in the need for teachers to assume this role as well. All in all, there are radical changes in the work process which negatively impact the subjective dimension of university professors ${ }^{(3-5,9)}$.

Another factor which strongly impacted teachers' lives after the insertion of the neoliberal model was the introduction of new technologies such as computers, smartphones, and highly complex machines, among others. The emergence of these technologies had a great impact on the teaching category regarding learning new technologies related to nursing care, conducting academic activities and breaking boundaries between life-work spheres ${ }^{(10)}$.

It follows that several changes occurred in the Brazilian political-economic scenario after the advent of the neoliberal model which strongly impacted the world of teaching work. Based on the premise of the minimum state, key sectors (in particular health and education) have suffered negative consequences such as scarcity of material and personnel, leading to intensification and work overload. Moreover, the desired profile of the worker was also modified, giving priority to multipurpose and multifunctional professionals ${ }^{(6)}$.

Considering this theoretical contextualization involving the study focus, the following objectives were listed: 1. To describe the organization of the nursing professor's work; and 2. To analyze the limits and facilitating aspects of this work.

The present study seeks to contribute to a broader analysis of the transformations which have been occurring in the world of work from inserting the neoliberal model in labor organizations, and above all of the impacts of these transformations on the dynamics of nursing professors' work. It is necessary to raise such reflections in order to seek coping 
strategies and resistance to the fundamentals and the implications of this model for the teaching work process and for the health of these workers.

\section{METHOD}

\section{STUDY DESIGN}

This is a qualitative and descriptive study conducted in two public universities in the city of Rio de Janeiro which house nursing colleges. In order to maintain the confidentiality of these universities, they will be regarded as University $\mathrm{A}$ and University B.

\section{Population}

University A's faculty consists of 41 professionals and University B has 72 faculty members. Both undergraduate and postgraduate, lato sensu and stricto sensu (Master's and Doctorate) activities are carried out at both universities.

These universities were chosen because both are confined to the municipality of Rio de Janeiro, are public institutions and develop similar work processes. Therefore, the study sought to approximate contexts of teaching work and encompass a diversity of information and subjective experiences at the same time.

\section{SELECTION CRITERIA}

The participants are 27 professors, 14 from University $A$ and 13 from University B. The inclusion criteria were: teachers with a statutory employment relationship; teachers in full exercise of their functions for more than fifteen years in the investigated institutions. This time frame is based on the fact that this period is relevant for teachers to report the changes in the world of work from the advent of the neoliberal model in the context of the investigated universities.

The following aspects regarding exclusion criteria were considered: teachers on leave, on vacation or assigned to other institutions during the data collection period; and teachers directly involved with the present study (members of its examining board).

\section{DATA COllection}

Data collection took place through a semi-structured individual interview in May and June 2016. A researcher who was a Master's student at the time visited both Universities to approach the possible participants, inviting them to contribute to the study. All professors who were eligible to participate in the study were invited, the interviews were scheduled according to their availability, and no refusals were registered.

It is noteworthy that a quantitative balance of participants in the departments which comprised the investigated institutions was sought during the interview scheduling, and that the criterion of information recurrence was used to finalize the interviews ${ }^{(11)}$. Therefore, not all participants who agreed to participate in the survey were interviewed. An email was sent to these participants informing them about the closure of the interviews and thanking them for their availability. A code was created to refer to each participant starting with the letter "P" for professor, followed by the letter referring to the investigated institution and a number related to the order in which the interview was collected.

\section{DATA ANALYSIS AND PROCESSING}

Data were processed based on the content analysis technique $^{(12)}$ resulting in three categories: I) Activities developed in the daily teaching work; II) Facilitating factors of teaching work; and III) Limiting aspects of teaching work.

\section{ETHICAL ASPECTS}

Comprising the ethical precepts, this research was registered in the Platform Brazil of the Ministry of Health, as recommended by Resolution 466/2012 of the National Health Council, obtaining a positive opinion of the Ethics Committee with Protocol No. 1.474.463, of April 1, 2016. Those who agreed to participate signed the Informed Consent Form (ICF) in two copies, one being held by the research participant and the other under the domain of the lead researcher.

\section{RESULTS}

\section{ACTIVITIIES DEVELOPED IN DAILY TEACHING WORK}

The issue of the multiplicity of tasks performed by teachers is highlighted from analyzing the interviews, which encompass activities in the field of teaching, research, extension, and administrative activities. Eighteen (18) participants (66.7\%) indicated developing activities with undergraduates in the classroom and also in internship fields. A further 15 respondents $(55.5 \%)$ supervise undergraduate and lato sensu and stricto sensu postgraduate students. Such multiplicity of tasks is evidenced in the following speech:

We have many activities. I supervise Master's and Doctorate degrees, I teach theoretical and practical undergraduate classes, specialization classes, assist an extension project and still have all this administrative part of coordinating the postgraduate program (PB10).

From the perspective of the teacher's administrative activities, 14 participants (52\%) reported taking on some administrative position such as coordinating a postgraduate program, coordinating residencies, departmental head, academic support management, professional master's coordination, directorship of nursing school, postgraduate substitute coordination, undergraduate coordination, doctorate coordination, adjunct school board, adjunct undergraduate coordination and university hospital board.

From this point of view, pedagogical management activity intensifies the administrative work also assumed by teachers, as such activities involve submitting projects to funding agencies, scholarships, management of the academic system, etc. The demands of management positions are also added to this. Moreover, such an activity requires professionals to not only constantly improve in the educational field, but also in management. 
This association of teaching duties with administrative and management activities can be observed in the following statement:

As I am coordinator of the Postgraduate Program, my work routine is more focused on the administrative part. I take care of administrative or academic demands within the program. Then I provide service to teachers and students, and also answer the phone. I even have a concern with the students' academic system. It's too much (PA12).

Other activities indicated by the professors are: publishing scientific articles, reviewing articles for scientific journals, participating and organizing events, applying for extension and scientific initiation scholarships and competing in public notices in order to raise funds for the university.

This week there is a special task which is the Pibic [Institutional Program for Scientific Initiation Scholarships], because we have to submit the project to apply for scholarships. As we are permanent postgraduate teachers, we have to keep this up to date, Pibic scholarships, Pibiti scholarship [Institutional Program of Initiation Fellowships in Technological Development and Innovation], and go after research grants. I also review for scientific journals and need to publish (PB2).

The participants reveal that performing all of these assignments requires some background activities, sometimes imperceptible to students and co-workers. In this regard, they refer to the need to participate in numerous meetings and committees in order to plan the teaching duties, and adaptations and improvisations in confronting the adversities of daily work.

I also participate in committees in other sectors of the university. This requires report review and the various meetings it entails, and no one sees it. I usually start the research group meeting in the afternoon, which runs until 4 pm. Then I have another meeting with another research group from 4 to 5 (PA1).

This multiplicity of tasks has repercussions on the subjective dimension of the worker, because they go beyond formal working hours in order to cope with this labor demand and end up working from home.

I work from Monday to Friday at the university, but from Sunday to Sunday for the university, otherwise we can't handle it (PB11).

\section{FACILITATING FACTORS OF TEACHING WORK}

Facilitating factors for teaching work include: good work environment, autonomy and flexibility of working hours, quick access to various sectors of the university, pleasure in doing things and the use of technologies.

Regarding the good work environment, 11 participants (41\%) indicated collaboration and solidarity with peers as facilitating aspects of teaching work, as well as understanding students in confronting the adversities which form the world of public work in this time.

Facilitating aspects are linked to the bond we have, especially here in the department, people help each other a lot. If the person has a problem, whether personal or physical, we try to support that person. The students are also very interested and it helps a lot (PA13).

In addition to the good work environment, another factor pointed out as a facilitator of teaching work is liking what is done. This feeling is closely linked to the motivation and ability to develop quality work, leading to a feeling of satisfaction in relation to the results of their work.

I really like what I do, so for me, something facilitating is doing what I like. It is working with something that you identify with (PB5).

Another situation emphasized by the participants as a work facilitator is the autonomy that the university provides. This feature was addressed by six respondents (23\%), being specifically mentioned in relation to the freedom that teachers have to perform their tasks, such as the use of new teaching methodologies, and also the possibility to adjust their workload as they wish.

Within the public university you have the autonomy to create, invent, and test, and that helps maintain motivation. In addition, we have flexible schedules. For example, I arrived today at 10:00 am after reading my supervisee's work at home (PA14).

The use of technologies favoring good work development is also pointed as a facilitator by the teachers. The technology used by participants is mainly the internet, as the teacher can prepare classes and keep in touch with students outside the work space, as well as qualify and disseminate knowledge through articles in online databases.

As a teacher, technology has helped me improve class preparation, to search international and national journals. I applaud technology in that sense (PA8).

\section{LIMITING ASPECTS OF TEACHING WORK}

This category covers topics related to high demand, work pace, precarious working conditions and relationship difficulties.

The high demand for work is indicated by 12 teachers (44\%), mainly mentioning activities in the undergraduate and postgraduate level, highlighting tasks such as teaching, research, extension and management, in addition to other activities which support these such as meetings, administrative activities, and ongoing studies.

In addition to the high labor demand, teachers indicate an intensified work pace, as teachers end up performing activities simultaneously and with the work organization imposing pressure, so they handle their tasks as quickly as possible.

We are doing everything at the same time. And at this rate of work you end up not having time to talk to people. You don't have time to bave a cup of coffee without working. You bring the coffee to your desk and go to work, sometimes the coffee gets cold (PB8).

Regarding human resources, 14 respondents (52\%) indicate the low number of teachers as a difficulty, which requires these professionals to multitask and be multifunctional in order to meet the needs of university work. Apart from 
this lack of human resources, there is also a high number of students per class, requiring workers to have adaptive capacity and creativity to face the variability that involves relationships with students.

We are too few teachers to handle undergraduate, specialization courses, two master's degrees, a doctoral degree, in addition to the administrative issues which come with teaching, research, and extension. We also have a large number of students to follow in practical fields and to teach lectures (PA9).

Besides the low number of teachers, the work is difficult due to the deficiency of administrative technicians. Such deficiency requires that teachers, in addition to performing tasks inherent to their activity, also assume administrative tasks, thereby increasing their work demand and reinforcing the idea of versatility and multifunctionality.

One difficulty we have is the scarcity of administrative technicians. It would be interesting for a secretary to belp us in submitting projects and stuff. It would greatly facilitate the work, especially for teachers who are in postgraduate school (PB10).

The lack of material resources and infrastructure at the university is a highly representative issue, being mentioned by 18 professors $(63 \%)$. It is important to note that this difficulty is also pointed out in practical scenarios. It mainly addresses the difficulty related to the quantity and quality of items such as digital projectors, air conditioning, classrooms, administrative material, computers, and elevators, among others.

Complaints are made that the lab is not fully equipped, but there is no money to equip it properly. The elevator always breaks down, the right thing to do would be to buy another, but there is no money. So there's precariousness from the structural to funding issues, like having an up-to-date library, having data presentation capabilities. For example, we got an amazing simulator, but it's hard to get maintenance done on it (PA7).

Another difficult situation for teaching imposed by research and teaching funding agencies such as the Higher Education Personnel Improvement Commission (CAPESCoordenação de Aperfeiçoamento de Pessoal do Nivel Superior) and the National Council for Scientific and Technological Development (CNPq-Conselho Nacional de Desenvolvimento Cientifico e Tecnológico) is the demand for productivity.

In this perspective there is a vicious cycle since the teacher needs to publish articles to qualify their Lattes curriculum, which therefore enables raising funds for the university through research grants. Thus, teachers are more likely to get funding for teaching research and extension qualifications with the best placement of their curricula. However, as there is no specific budget for publishing articles, teachers withdraw resources from their salary to publish them, and consequently raise funds for the university. This situation also stimulates peer competitiveness, thus weakening interpersonal relationships in academia.

I think we have a lot of expenses here. Yesterday I was doing calculations on how much I spent on publishing last year and I saw that I spent $R \$ 3,800$ from my salary to publish articles. Granted, I like to publish and I even encourage students to do so, but I don't think that should be our obligation, or at least we should get specific funding for it (PA8).

Another situation emphasized by the participants which compromises good interpersonal relationships and in turn interferes with work accumulation is the inadequate distribution of the activities by the body of workers. The tripod of the Brazilian university is teaching, research and extension, and the teacher should organize activities in the undergraduate and postgraduate programs based on these instances. Thus, as some professors only teach undergraduate students, they impute on the colleagues the other needs of the institution.

There are those who only teach undergraduate classes and think they don't have to do anything else. Of course, this is an option, however, the teaching position you develop carries specific assignments. So, I can't understand how an associate professor who has a doctorate and knows what a teacher's assignments are in this position only teaches undergraduate classes and doesn't get involved in other activities (PB7).

\section{DISCUSSION}

The work of the nursing professor in a university is intense, complex and multifaceted, presenting high psycho-affective, cognitive and physical demands, because in addition to teaching lectures, the teacher also accompanies students in practical activities and supervised internships. Also linked to teaching activities in the theoretical and practical fields, in developing research guidelines and extension, sharing and offering the technical and scientific knowledge to the community, the teacher further acts in administrative activities and actively participates in the management $\operatorname{area}^{(13)}$.

The need to perform administrative tasks exhausts teachers since they perceive such activities as an obstacle to academic production because instead of performing teaching activities, they perform tasks which a properly trained administrative officer could perform ${ }^{(14)}$.

With the rise of postgraduate programs in Brazilian universities, university professors, who previously concentrated their activities and orientation in undergraduate studies, also began to supervise in the field of postgraduate studies. Moreover, it is strongly recommended that professors produce knowledge through research, thus making new discoveries which should be published as articles in scientific journals with high national or even international impact ${ }^{(15)}$.

In this sense, publications themselves are not necessarily a problem; the obstacle in this context is the excess of publications required based on an exacerbated neoliberal productive logic. Such logic is not compatible with specifically intellectual work. Research, producing new studies and publishing articles are generally important to foster knowledge development and progress. However, knowledge needs time to be developed and cannot be realized in a productivist logic, of reaching organizational goals which simply aim at the academic rise of the professor ${ }^{(15)}$.

Thus, the university which emerged with the premise of a social institution searching for knowledge autonomy in confronting religion and the state, seems to have succumbed to the neoliberal productivist logic, and is now governed by 
a market perspective. In times of low investment in research, the scramble for fundraising has become fierce, and with productivity being one of the prerequisites for funding, it has taken on a unique role in the university environment ${ }^{(16)}$.

As a result of this exacerbated focus on publication, what has been observed is the practice of "salami slicing", in which results which are only suitable for one article are sliced into other materials to ensure a greater quantity of publications. There is consequently low innovation, little creativity, superficial analysis and even increased fraud such as plagiarism and especially self-plagiarism ${ }^{(17)}$.

In addition to the demand for productivity through scientific publications, professors still need to teach and advise their students, review for scientific journals, provide ad hoc consultancy, prepare research reports, organize and participate in scientific events, apply for edicts and request scholarships from the funding agencies, among other activities which have exacerbated the pace of work of these professionals ${ }^{(18)}$. This acceleration in the work rhythm and a devaluation of the teaching career are factors which generate competitiveness, stress, suffering and illness among these professionals ${ }^{(15)}$. This situation is also linked to the neoliberal logic of intensifying production, versatility and competitiveness among workers in order to leverage results for the work organization $^{(3,15)}$.

Another factor which has led to an increase in labor demand and the work pace and equally pointed to as a hindering aspect is the lack of resources, both human and material, as well as the university's physical structure. The inadequacy of resources and working conditions, in addition to causing psychological distress, leads workers to modify their practices, adjusting the work process with adaptations and improvisations so as to supply this scarcity of resources, which may even compromise the work quality offered ${ }^{(13)}$. This situation is articulated with the neoliberal idea of the public machine, of the minimum State and the state's release of liability for basic sectors such as education ${ }^{(1,3,13)}$.

However, there are also facilitating aspects in the midst of the various difficulties listed by participants for developing teaching work such as good interpersonal relationships and solidarity among co-workers.

From this perspective, the social relationships which enable establishing cordiality and/or friendship with the work group are beneficial for both workers' health and work organization, making the worker produce more and better. When working relationships are favorable and present respect, dialogue, listening, interaction and camaraderie, the workers' pleasure and subjectivity are preserved, as well as the health and well-being of the professional collective ${ }^{(3,6)}$.

Another element highlighted as favoring the teaching work is liking what is accomplished, something fundamental for the professor to effectively develop their skills and to create well-being situations in the work environment. Self-fulfillment needs refer to the comprehensive fulfillment of the individual, growth, and professional and personal satisfaction $^{(3,13)}$.

Schedule flexibility and autonomy in the work process are also elements which contribute to developing teaching work. The possibility of changing the task prescription in order to adapt it to the work's reality promotes an exercise of practical intelligence, enables professionals to create new operative modes when necessary and makes them perform their work satisfactorily ${ }^{(4)}$.

Such practice is threatened by the recent proposal of electronic points in public educational institutions. Under the justification of equitably standardizing the working hours of professionals, they are now subjected to another form of control through this model ${ }^{(19)}$. It is verified that such a model uses different measures which aim to increase productivity, in addition to dictating the work pace of these professionals $^{(1,19)}$.

Differently from technical professionals, who work exclusively at the institution, professors sometimes need to work at different times or even in other environments, since a calm and quiet place is needed in order to perform intellectual work. Such a practice would not have a positive impact on these professionals, and could cause dissatisfaction among professors who see flexibility and autonomy as some of the advantages of their professional practice.

From another perspective, technology is understood as an important tool for the good progress of teaching work. For example, the Internet facilitates access to learning resources and improves teacher-student interaction, as it is a dynamic and interactive resource which enables new ways of teaching and learning, offering a variety of benefits in the learning process ${ }^{(20)}$.

Other forms of technology also favor teaching work, such as digital data projectors for showing lectures, computer labs, interactive whiteboards which provide more dynamic classes and realistic simulation labs which enable acquiring technical-scientific knowledge and psychomotor skills, even before students are inserted into practical scenarios ${ }^{(10)}$.

The use of teaching tools which make the teaching-learning process more dynamic has positive repercussions for both students and professors. Such tools stimulate creativity, innovation and proactivity, making students more active and involved in the teaching-learning process. In turn, the teachers feel gratified because when they realize that the student is involved with their work, they have pleasant feelings about it ${ }^{(10,20)}$.

Although technology is an important ally in teacher productivity, it causes work to invade the home space, compromising the relationship with family members and workers' rest $^{(15)}$. In this sense, with the advent of the Internet and due to the various ways to access it (mobile, computer and tablets), it is possible to work anytime and anywhere, which has been called "boundaryless work", a term which has been applied in the international literature to characterize the loss of boundaries between life and work ${ }^{(21)}$.

Thus, insertion of the neoliberal model not only changed the teaching work routine, but also the personal life of these professionals. In addition to the various factors which hinder this work, some facilitating aspects are threatened as in the case of time flexibility, or even present themselves dialectically, both positively and negatively, as in the example of technology. 


\section{CONCLUSION}

The results show that the teaching work nowadays comprises a diversity of tasks, with hindering aspects being more common in the participants' statements than facilitators for its execution. As facilitators, the good work environment, autonomy, flexibility, a love for the work, using technologies and the solidarity of the professional collective stand out.

The hindering elements were more representative and are closely linked to the organization of work based on the neoliberal model. These were pointed out by the interviewees of this research as being the high demand of work, the intense work rhythm, the scarcity of material and human resources and the academic competitiveness.

Given the results, it is necessary to create organizational measures with less demands and less workload. However, such measures are contrary to the premises of the neoliberal model, which aims to reduce the public machine and maximize profits, thereby abandoning workers to their own destiny.

A movement by workers, especially those who are aware of the negative effects of this model, is necessary to encourage other professionals to reflect on this unusual situation, seeking to promote debates in the professional collective in order to form a critical mass which would be better able to resist the consolidation of this productive model in educational and health organizations.

It is proposed that these workers seek to engage in political movements by participating in acts and suggesting measures that will guarantee worker rights. It is critical that the category creates a string of claims based on macroeconomic issues, and not just technical ones.

It will only be possible for the university to cease to be just a place for building knowledge succumbed by productivity logic and to resume its premise of social criticism with a collective group of professionals who are empowered by cultural capital and who resist such a model.

\section{RESUMO}

Objetivo: Descrever a organização do trabalho do docente de enfermagem e analisar seus aspectos limitadores e facilitadores. Método: Pesquisa qualitativa e descritiva, composta por docentes de universidades públicas federais do Rio de Janeiro. A coleta de dados ocorreu em por meio de entrevista semiestruturada. A técnica para o tratamento dos dados foi a análise de conteúdo. Resultados: Participaram 27 docentes. Os elementos facilitadores do trabalho docente foram: ambiente de trabalho; autonomia e flexibilidade; gosto pelo que faz; uso das tecnologias; e solidariedade do coletivo profissional. Os elementos dificultadores foram: alta demanda de trabalho; ritmo laboral intenso; escassez de recursos material e humano; e competitividade acadêmica. Conclusão: A configuração da organização laboral docente é complexa e multifacetada, apresentando alta exigência psicoafetiva, cognitiva e física, o que potencializa o adoecimento desses trabalhadores.

\section{DESCRITORES}

Docentes de Enfermagem; Condições de Trabalho; Modelos Econômicos; Saúde do Trabalhador.

\section{RESUMEN}

Objetivo: Describir la organización del trabajo del docente de enfermería y analizar sus aspectos limitadores y facilitadores. Método: Investigación cualitativa y descriptiva, compuesta de docentes de universidades públicas federales de Río de Janeiro. La recolección de datos ocurrió mediante entrevista semiestructurada. La técnica para el tratamiento de los datos fue el análisis de contenido. Resultados: Participaron 27 docentes. Los elementos facilitadores del trabajo docente fueron: ambiente laboral; autonomía y flexibilidad; aprecio por lo que hace; empleo de las tecnologías; y solidaridad del colectivo profesional. Los elementos dificultadores fueron: alta demanda de trabajo; ritmo laboral intenso; escasez de recurso material y humano; y competitividad académica. Conclusión: La configuración de la organización laboral docente es compleja y multifacética, presentando alta exigencia psicoafectiva, cognitiva y física, lo que potencia que se enfermen dichos trabajadores.

\section{DESCRIPTORES}

Docentes de Enfermería; Condiciones de Trabajo; Modelos Económicos; Salud Laboral.

\section{REFERENCES}

1. Braverman H. Trabalho e capital monopolista: a degradação do trabalho no século XX. Rio de Janeiro: LTC; 2011. A habituação do trabalhador ao modo capitalista de produção; p. 124-34.

2. Pires AS, Ribeiro LV, Souza NVDO, Sa CMS, Gonçalves FGA, Santos DM. A permanência no mundo do trabalho de profissionais de enfermagem com possibilidade de aposentadoria. Ciênc Cuid Saúde. 2013;12(2):338-45. DOI: https://10.0.15.185/cienccuidsaude. v12i2.18298

3. Dejours C. A metodologia em psicodinâmica do trabalho. In: Lancman S, Sznelwar LI, organizadores. Christophe Dejours: da psicopatologia à psicodinâmica do trabalho. $3^{\mathrm{a}}$ ed. Rio de Janeiro: Fiocruz; 2011. p. 105-26.

4. Davoglio TR, Timm JW, Santos BS, Conzatti FBK. Necessidades psicológicas básicas: definições operacionais na docência universitária. Educ Temática Digital. 2017; 19(2):510-31. DOI: https://doi.org/10.20396/etd.v19i2.8644789

5. Antunes R. Adeus ao Trabalho? Ensaio sobre as metamorfoses e a centralidade do mundo do trabalho. $14^{\mathrm{a}}$ ed. São Paulo: Cortez; 2011.

6. Gonçalves FGA, Souza NVDO, Pires AS, Santos DM, D'Oliveira CAFB, Ribeiro LV. Modelo neoliberal e suas implicações para a saúde do trabalhador de enfermagem. Rev Enferm UERJ [Internet]. 2014 [citado 2015 jul 27];22(4):519-25. Disponível em: http://www.facenf. uerj.br/v22n4/v22n4a14.pdf

7. Borges TS, Alencar G. Metodologias ativas na promoção da formação crítica do estudante: o uso das metodologias ativas como recurso didático na formação crítica do estudante do ensino superior. Cairu Rev. 2014;3(4):119-43. 
8. Silveira RCP, Ribeiro IKS, Teixeira GS, Teixeira LN, Souza PHA. Estilo de vida e saúde de docentes de uma instituição de ensino pública. Rev Enferm UFSM [Internet]. 2017 [citado 2019 abr 15];7(4): 601-14. Disponível em: https://periodicos.ufsm.br/reufsm/article/view/24713

9. Hood LJ. Conceptual bases of professional nursing. Philadelphia: Wolters Kluwer Health; 2014.

10. Silveira MS, Cogo ALP. Contribuições das tecnologias educacionais digitais no ensino de habilidades de enfermagem: revisão integrativa. Rev Gaúcha Enferm. 2017;38(2):1-9. DOI: http://dx.doi.org/10.1590/19831447.2017.02.66204

11. Minayo, MCS. O desafio do conhecimento: pesquisa qualitativa em saúde. 12a ed. São Paulo: Hucitec-Abrasco; 2010.

12. Bardin L. Análise de conteúdo. Lisboa: Edições 70; 2011.

13. Lemos MC, Passos JP. Satisfação e frustração no desempenho do trabalho docente de enfermagem. Rev Min Enferm [Internet]. 2012 [citado 2019 abr. 15];16(1). Disponível em: http://www.reme.org.br/artigo/detalhes/499

14. Santos CC, Pereira F, Lopes A. Experiences of management activities in university teaching. Educ Real 2018;43(3):998-1008. DOI: https:// dx.doi.org/10.1590/2175-623674106

15. Borsoi ICF, Pereira FS. Professores do ensino público superior: produtividade, produtivismo e adoecimento. Univ Psychol. 2013;12(4). DOI: 10.11144/Javeriana.UPSY12-4.peps

16. Paini LD, Costa LP. A função social da universidade na contemporaneidade: algumas considerações. Revista Even Pedagog [Internet]. 2016 [citado 2019 maio 25];7(1):59-72. Disponível em: sinop.unemat.br/projetos/revista/index.php/eventos/article/download/2077/1701

17. Iriart JAB, Deslandes SF, Martin D, Camargo KR, Carvalho MS, Coeli CM. A avaliação da produção científica nas subáreas da saúde coletiva: limites do atual modelo e contribuições para o debate. Cad Saúde Pública. 2015;31(10):2137-47. DOI: http://dx.doi.org/10.1590/0102$311 \times 00065515$.

18. Almeida LP. Universidade, alienação e capitalismo. Rev Espaço Livre [Internet]. 2015 [citado 2016 dez. 21];10(20):45-54. Disponível em: http://redelp.net/revistas/index.php/rel/article/view/319/348

19. Ribeiro CVS, Leda DB. O trabalho docente no enfrentamento do gerencialismo nas universidades federais brasileiras: repercussões na subjetividade. Educ Rev. 2016, 32(4):97-117. DOI: http://dx.doi.org/10.1590/0102-4698161707.

20. Landeiro MJL, Freire RMA, Martins MM, Martins TV, Peres HHC. Educational technology in care management: technological profile of nurses in Portuguese hospitals. Rev Esc Enferm USP. 2015;49(spe2):150-5. DOI: http://dx.doi.org/10.1590/S0080-623420150000800021

21. Mellner C, Kecklund G, Kompier M, Sariaslan A. Boundaryless Work, Psychological detachment and sleep: does working 'anytime anywhere' equal employees are 'always on'? In: De Leede, J, editor. New ways of working practices. Bingley: Emerald Group; 2016, p. $29-47$. 